\section{Suitability of Eight Northeastern U.S. Native Shrubs as Replacements for Invasive Plants in a Difficult Landscape Site with White-tailed Deer Pressure}

\author{
Pragati Shrestha ${ }^{1}$ and Jessica D. Lubell ${ }^{2,3}$
}

\begin{abstract}
AdDitional Index wORDs. creeping sand cherry, Prunus pumila var. depressa, 'Compactus' winged euonymus, Euonymus alatus, 'Crimson Pygmy' japanese barberry, Berberis thunbergii, elderberry, Sambucus canadensis, gray dogwood, Cornus racemosa, highbush blueberry, Vaccinium corymbosum, round leaf dogwood, Cornus rugosa, northern spicebush, Lindera benzoin, sweetbells, Eubotrys racemosa, virginia rose, Rosa virginiana
\end{abstract}

SuMMARY. Nursery and landscape professionals are interested in white-tailed deer (Odocoileus virginianus)-resistant native plants to replace invasive species used in difficult landscape sites, such as parking lot islands, which are dry, nutrient-poor, and exposed to sun and heat. Eight native shrubs [creeping sand cherry (Prunus pumila var. depressa), elderberry (Sambucus canadensis), gray dogwood (Cornus racemosa), highbush blueberry (Vaccinium corymbosum), round leaf dogwood (Cornus rugosa), northern spicebush (Lindera benzoin), sweetbells (Eubotrys racemosa), and virginia rose (Rosa virginiana)] were planted in a large commuter parking lot on the University of Connecticut campus to evaluate their suitability for use in difficult landscapes. The non-native, invasive shrubs 'Compactus' winged euonymus (Euonymus alatus) and 'Crimson Pygmy' japanese barberry (Berberis thunbergii) were also planted as controls representing non-native species typically planted in such sites. Aesthetic quality ratings for sweetbells matched the controls (rating of 4.5 out of 5.0) and plants exhibited a high level of white-tailed deer resistance. Virgina rose and creeping sand cherry had similar aesthetic quality to controls, despite light grazing of plants by white-tailed deer. Elderberry was damaged by moderate white-tailed deer grazing and snow load, but plants regenerated to $485 \%$ of initial size in one growing season with white-tailed deer exclusion. Gray dogwood, round leaf dogwood, and northern spicebush exhibited the least resistance to white-tailed deer grazing. Both dogwood species had lower aesthetic quality than the controls, and round leaf dogwood had the lowest survival rate $(68 \%)$ after 2 years. However, several individuals of gray dogwood, round leaf dogwood, and northern spicebush that were less heavily damaged by white-tailed deer grew into attractive shrubs after white-tailed deer exclusion. Highbush blueberry had significantly lower aesthetic quality than controls and only $75 \%$ survival after 2 years, indicating that this species is an unsuitable replacement for invasives in difficult landscape sites. This study identified the underused native shrubs sweetbells, virginia rose, and creeping sand cherry as suitable replacements for invasives in difficult landscape sites with white-tailed deer pressure.

$\mathrm{T}$ The sustainable landscape featuring native plants is a rapidly expanding trend in horticulture. Native plants support wildlife, including pollinators, and are not invasive (Tallamy, 2007). Some of the most popular and widely used plants for landscaping have been found to be invasive, and sales of these plants have declined dramatically in recent years (McCoy 2011). Two such invasive

Department of Plant Science and Landscape Architecture, University of Connecticut, 1376 Storrs Road, Unit 4067, Storrs, CT 06279-4067

${ }^{1}$ Graduate Assistant

${ }^{2}$ Assistant Professor

${ }^{3}$ Corresponding author. E-mail: jessica.lubell@uconn.edu. shrubs are japanese barberry and winged euonymus. Ironically, some of the same traits that brought japanese barberry and winged euonymus horticultural prominence are also what makes them invasive (Lehrer et al., 2006). The most obvious and important of these traits is their ability to perform well in variable environmental conditions, including difficult landscape sites. Furthermore, high white-tailed deer pressure on many landscapes necessitates the need for white-tailed deer-resistant ornamental plants.

The replacement of invasive plants with native plants is a desirable solution to the invasive plant problem (Gagliardi and Brand, 2007). Not all native plants will tolerate difficult landscape conditions, that include dry, nutrient-poor soils, and exposure to high sunlight, heat and wind, and damage from pedestrians, as well as japanese barberry and winged euonymus (Lubell, 2013). The direct replacement of japanese barberry and winged euonymus with native shrubs requires research to identify species that are suitable for difficult landscape conditions. Based on observations of diverse natural habitats, we identified the following eight underused native shrubs as potential candidates for use as invasive plant alternatives: creeping sand cherry, elderberry, gray dogwood, highbush blueberry, round leaf dogwood, northern spicebush, sweetbells, and virginia rose. The objective of this study was to determine whether these eight native shrubs are well adapted to landscape use. The identification of well-adapted native shrubs will enable the nursery industry to offer a broader palette of native plants for use in landscaping that will be profitable over time.

\section{Materials and methods}

Eight Northeastern U.S. native shrub species (creeping sand cherry, elderberry, gray dogwood, highbush blueberry, round leaf dogwood, northern spicebush, sweetbells, and virginia rose; Table 1) were selected for this study. Elderberry, gray dogwood, round leaf dogwood, northern spicebush, and virginia rose were sexually propagated and creeping sand cherry, highbush blueberry, and sweetbells were asexually propagated from individual stock plants.

\begin{tabular}{llll}
\hline $\begin{array}{l}\text { Units } \\
\text { To convert U.S. to SI, } \\
\text { multiply by }\end{array}$ & U.S. unit & SI unit & $\begin{array}{l}\text { To convert SI to U.S., } \\
\text { multiply by }\end{array}$ \\
\hline 0.3048 & $\mathrm{ft}$ & $\mathrm{m}$ & 3.2808 \\
3.7854 & gal & $\mathrm{L}$ & 0.2642 \\
2.54 & inch(es) & $\mathrm{cm}^{3}$ & 0.3937 \\
16.3871 & inch $^{3}$ & $\mathrm{~cm}^{3}$ & 0.0610 \\
28.3495 & $\mathrm{oz}$ & $\mathrm{g}$ & 0.0353 \\
0.9464 & $\mathrm{qt}$ & $\mathrm{L}$ & 1.0567
\end{tabular}


Table 1. Nomenclature and plant description of eight Connecticut native shrub species. Plant descriptions are based on observations in Connecticut and literature sources.

\begin{tabular}{|c|c|c|}
\hline $\begin{array}{l}\text { Common } \\
\text { name }\end{array}$ & $\begin{array}{l}\text { Source } \\
\text { of plant }\end{array}$ & Plant description ${ }^{\mathrm{z}}$ \\
\hline $\begin{array}{l}\text { Creeping } \\
\text { sand cherry }\end{array}$ & Cutting & $\begin{array}{l}\text { Groundcover, less than } 1 \mathrm{ft} \text { tall. White flowers in early spring as the foliage emerges. Slender, } 1 \text { to } 3 \\
\text { inches long, simple alternate leaves are lime green with silver undersides and turn orange-red in fall. } \\
\text { Small black fruit ripen in fall. }\end{array}$ \\
\hline Elderberry & Seed & $\begin{array}{l}\text { Multistemmed, upright spreading habit ( } 5 \text { to } 10 \mathrm{ft} \text { tall). Coarse-textured plant with stout stems and } \\
\text { large opposite compound leaves with } 5 \text { to } 11 \text { serrate leaflets. Large flat-topped inflorescences of } \\
\text { small white star-shaped flowers. Edible purple-black berries in late summer. }\end{array}$ \\
\hline $\begin{array}{l}\text { Highbush } \\
\text { blueberry }\end{array}$ & Cutting & $\begin{array}{l}\text { Upright, spreading habit ( } 6 \text { to } 12 \mathrm{ft} \text { tall). Alternate, simple leaves are dark green to dark blue-green in } \\
\text { summer and turn red in fall. Small, white urn-shaped flowers in early spring. Edible berries ripen } \\
\text { blue-black in summer. }\end{array}$ \\
\hline $\begin{array}{l}\text { Round leaf } \\
\text { dogwood }\end{array}$ & Seed & $\begin{array}{l}\text { Upright, spreading habit ( } 6 \text { to } 10 \mathrm{ft} \text { tall) with stout stems. Large, rounded opposite leaves. Stems } \\
\text { develop coral red coloration in winter and feature interesting lenticels. Small white flowers in dense, } \\
\text { flat-topped, } 2 \text {-inch diameter clusters. Fruit transition from green to white to robin's egg blue to } \\
\text { amethyst in summer. }\end{array}$ \\
\hline Sweetbells & Cutting & $\begin{array}{l}\text { Upright shoots end in arching twigs. Open-grown plants are multistemmed and reach } 3 \text { to } 6 \mathrm{ft} \text { tall. } \\
\text { Alternate, simple leaves are } 1 \text { to } 3 \text { inches long. Glossy foliage emerges with reddish cast, turns dark } \\
\text { green in summer, and scarlet red in fall. Small, white urn-shaped, flowers emerge on one-sided } \\
\text { racemes and give off light fragrance. In winter, twigs and naked flower buds develop reddish } \\
\text { coloration. }\end{array}$ \\
\hline Virginia rose & Seed & $\begin{array}{l}\text { Low growing ( } 2 \text { to } 4 \mathrm{ft} \text { tall) with upright shoots and a dense, rounded habit. Alternate, compound } \\
\text { leaves with } 5 \text { to } 9 \text { coarsely toothed leaflets. Glossy dark green foliage turns orange-red in fall. } \\
\text { Fragrant, five-petal pink flowers }(2 \text {-inch to } 3 \text {-inch diameter), solitary or in small groups, bloom in } \\
\text { summer. Numerous fruit ( } 1 / 2 \text {-inch to } 1 \text {-inch diameter) ripen red-orange in fall and persist through } \\
\text { winter. }\end{array}$ \\
\hline
\end{tabular}

${ }^{\mathrm{z}}$ Information adapted from Cullina (2002), Dirr (2011), and Hightshoe $(1988) ; 1 \mathrm{inch}=2.54 \mathrm{~cm}, 1 \mathrm{ft}=0.3048 \mathrm{~m}$.

Elderberry, gray dogwood, and virginia rose were obtained in \#l containers (3 qt) from New England Wetland Plants Inc. (Amherst, MA). Spicebush was obtained in \#1 containers from Planter's Choice Nursery (Newtown, CT). Highbush blueberry was obtained in \#2 containers (7 qt) from Prides Corner Farms (Lebanon, CT). Creeping sand cherry, round leaf dogwood, and sweetbells were propagated and grown by the authors and finished in \#l containers at the University of Connecticut (UConn) Plant Science Research and Education Facility (Storrs, CT). Plants were installed in parking lot islands in a commuter parking lot on the UConn campus (Storrs, CT) in USDA hardiness zone 6 a on 1 June 2012. Two nonnative, invasive species, 'Crimson Pygmy' japanese barberry and 'Compactus' winged euonymus, were also planted and used as controls. These species were asexually propagated and were obtained in \#2 containers from Prides Corner Farms.

The experimental design was a randomized complete block design with five replications and the experimental unit consisted of five individual plants. A block consisted of a planting row, which was divided into ten equal experimental units each containing five plants of a species. Each block contained 50 plants and 250 plants in total were installed for the study. Three blocks were installed in a single parking lot island and two blocks in a separate parking lot island. Each block was within $5 \mathrm{ft}$ of asphalt parking lot or concrete sidewalk. One week before planting, block perimeters were marked and the grassy vegetation was sprayed with glyphosate herbicide. Shrubs were installed with the top of the root ball at or slightly higher than the surrounding landscape soil. Plants were arranged in two staggered rows with 4 - $\mathrm{ft}$ centers within row and $3 \mathrm{ft}$ between rows. The five individual plants per experimental unit were arranged so that three plants occupied one row and two plants occupied the other row in adjacent positions. Blocks were mulched with shredded softwood bark to a depth of 3 inches. Plants were irrigated by hand with a watering wand immediately after planting, three times weekly for the first 4 weeks and twice weekly for the next 6 weeks. Each shrub was irrigated with $\approx 3$ L of water at each irrigation event. After the 10 weeks following planting, shrubs did not receive supplemental irrigation for the remainder of the study. Plants did not display visible signs of drought stress for the duration of the study. Plants were fertilized on 22 Apr. 2013 and 24 Apr. 2014 with $30 \mathrm{~g}$ of granular 10N$4.4 \mathrm{P}-8.3 \mathrm{~K}$ in the area 12 to 24 inches from the crown. Blocks were mulched a second time on 22 May 2013 with shredded softwood bark to a depth of 2 inches. The soil at the parking lot site 
had sandy loam texture, $\mathrm{pH}$ 6.1, and $3.5 \%$ organic matter.

Plant height and width were measured at time of planting in June 2012 and at 106 weeks after planting (WAP) on 26 June 2014. Plant width was measured twice, at right angles to each measurement, and averaged. Plant size was calculated as the product of the height and two perpendicular widths. Percent change in plant size was calculated using the formula: (size at $106 \mathrm{WAP}$ - initial size/initial size) $\times 100 \%$. Plant survival was evaluated during the third week of June 2013 and 2014.

Since damage from white-tailed deer browse was so prevalent for several study species during the 2013 growing season, the severity of white-tailed deer damage was evaluated using a visual rating. On 19 June 2013, plants were rated for severity of white-tailed deer damage using a scale of 1 to 5 , where 1 represented no damage, 2 represented slight damage (some shoot tips browsed), 3 represented moderate damage (majority of shoot tips browsed), 4 represented moderate to heavy damage (shoot tip browse and some shoots browsed to half original length or more), and 5 represented heavy damage (most shoots browsed to half original length or more).

On 25 Apr. 2014, a fence was erected around each of the study blocks to prevent white-tailed deer browsing during the 2014 growing season so that the plants could be evaluated in 2014 for aesthetic quality without the impact of white-tailed deer browse. On 26 June 2014, all plants were visually rated for aesthetic quality based on uniformity of shape and density of foliage using a scale of 1 to 5 where 1 represented a sparse, asymmetrical plant, 2 represented an asymmetrical plant with some sparse sections, 3 represented a dense, asymmetrical plant, 4 represented a dense, slightly asymmetrical plant, and 5 represented a dense, uniformly proportional plant. For elderberry, round leaf dogwood, and northern spicebush, there was one experimental unit in 2014 that had zero or only one surviving plant, and these were not evaluated for aesthetic quality. Therefore, aesthetic quality ratings for elderberry, round leaf dogwood, and northern spicebush were based on four replications instead of five.

For the white-tailed deer damage severity rating and the aesthetic quality rating, three independent observers rated each plant and the three observations were averaged. Percent survival data were transformed using arcsine for mean separation analysis. Data were subjected to analysis of variance using the PROC MIXED procedure and mean separation using Fisher's least significant difference test $(P \leq$ 0.05 ) using SAS (version 9.2 for Windows; SAS Institute, Cary, NC).

\section{Results and discussion}

All of the native species, except for northern spicebush, survived the first winter as well as the non-native controls 'Crimson Pygmy' japanese barberry and 'Compactus' winged euonymus, which had $100 \%$ survival (Table 2). Survival of northern spicebush $(88 \%)$ may have been reduced by the full sun conditions at the parking lot sites since this plant grows naturally in partly to mostly shade of the forest understory. The plants that did survive grew well in full sun. First-year survival rates for the other native species ranged from $92 \%$ to $100 \%$ (Table 2 ).

The parking lot sites on the UConn campus were frequently visited by white-tailed deer, and white-tailed deer browse was observed on many species. Native sweetbells and highbush blueberry never had white-tailed deer damage [rating of 1 Table 2)] and exhibited a high level of white-tailed deer resistance. The non-native 'Crimson Pygmy' japanese barberry was also undamaged by white-tailed deer during this study. Native virginia rose and creeping sand cherry had slight whitetailed deer damage, where some shoot tips were browsed, which was similar to the ratings of non-native control 'Compactus' winged euonymus (1.8). Significantly more white-tailed deer damage was found on elderberry, round leaf dogwood, gray dogwood, and northern spicebush, which had ratings of $2.9,3.0,3.4$, and 4.0 , respectively. These plants had most of their shoot tips browsed with substantial leaf removal for some species and occasional shoots were browsed to half their original height. Our findings about the degree of white-tailed deer damage for japanese barberry, winged euonymus, and elderberry generally support the deer-resistance ratings by Perdomo et al. (2004), in their extension bulletin for the state of New Jersey. However, our results for highbush blueberry and northern spicebush contradict the New Jersey ratings for these plants. We found that highbush blueberry was substantially more white-tailed deer-resistant than northern spicebush.

After the second winter, there was plant attrition for all of the native species except for virginia rose (Table 2). Northern spicebush had similar plant attrition in both the first and second years, with $76 \%$ of plants surviving after 2 years. Attrition of highbush blueberry doubled in year two, resulting in $75 \%$ survival after 2 years. Creeping sand cherry and elderberry had $100 \%$ survival in year one, but after the second winter, survival was $88 \%$ and $80 \%$, respectively. Round leaf dogwood also had $100 \%$ survival in year one, but losses during the second winter were substantial, with only $68 \%$ of plants surviving after 2 winters. Plant attrition after the second winter for sweetbells and gray dogwood was slight at $4 \%$. After 2 years, survival for all of the native species was similar to the non-native control 'Crimson Pygmy' japanese barberry, and survival for round leaf dogwood was less than that for the non-native control 'Compactus' winged euonymus.

Plant attrition, growth, and aesthetic quality were impacted by factors including: 1) the inherent suitability of the species to the difficult parking lot landscape, 2) varying amounts of whitetailed deer browse and the species ability to recover from white-tailed deer browse, and 3 ) substantial impacts from heavy snowfalls and snow removal practices over Winter 2013-14. The town of Storrs, CT, had 54 inches of snow during the months of Jan. and Feb. 2014 (U.S. Department of Commerce, 2009a, 2009b), and its removal from parking lots required extraordinary measures and large equipment, which resulted in heavy amounts of snow being piled on the study plantings and snow plow blades hitting plants.

Over the course of the study, most native plants increased in size, while a few decreased in size (Table 3 ). Both of the non-native controls increased in size. Elderberry exhibited substantial percent increase in plant size $(485 \%)$, which is primarily due to this species fast growth rate (Dirr, 2011), but is also indicative of an ability to overcome white-tailed deer browsing and snow load impacts. Sweetbells, virginia rose, round leaf dogwood, and northern spicebush also showed increases in plant size. Creeping sand 
Table 2. One-year survival and severity of white-tailed deer damage in 2013 and 2-year survival and aesthetic quality in 2014 of eight Connecticut native and two non-native shrub species planted in a commuter parking lot on the University of Connecticut campus (Storrs, CT).

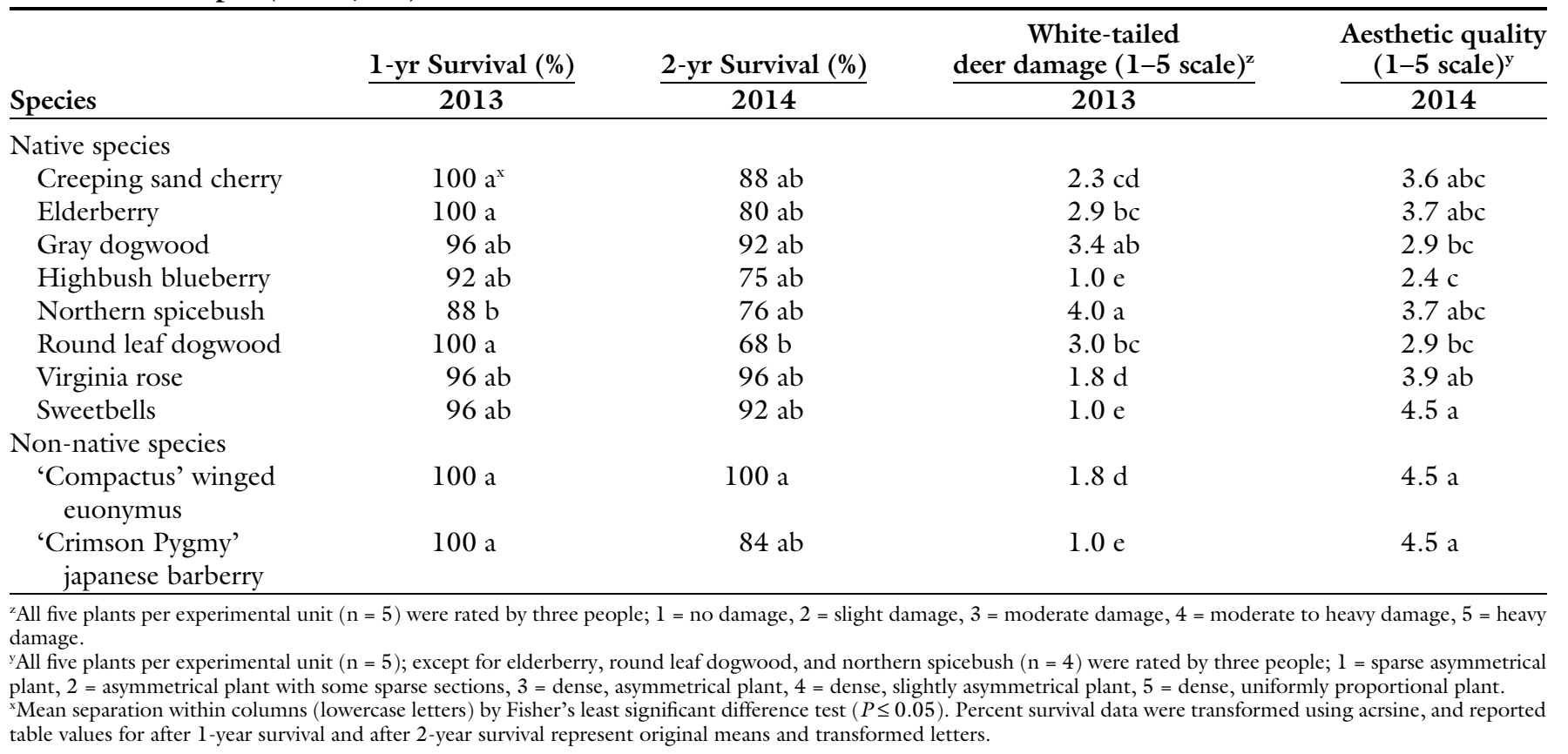

Table 3. Height, width, and size at time of planting (initial) and 106 weeks after planting (WAP) and percent change in plant size over three growing seasons $(2012$ to 2014$)$ for eight Connecticut native and two non-native shrub species planted in a commuter parking lot on the University of Connecticut campus (Storrs, CT).

\begin{tabular}{|c|c|c|c|c|c|c|c|}
\hline \multirow[b]{2}{*}{ Species } & \multicolumn{3}{|c|}{ Initial } & \multicolumn{3}{|c|}{106 WAP } & \multirow[b]{2}{*}{$\begin{array}{c}\text { Change in } \\
\text { plant size (\%) }\end{array}$} \\
\hline & $\begin{array}{c}\mathrm{Ht} \\
\text { (inches) }^{\mathrm{z}}\end{array}$ & $\begin{array}{c}\text { Width } \\
\text { (inches) }^{\mathrm{y}}\end{array}$ & $\begin{array}{c}\text { Size } \\
\left(1000 \text { inch }^{3}\right)^{x}\end{array}$ & $\begin{array}{c}\mathrm{Ht} \\
\text { (inches) }\end{array}$ & $\begin{array}{l}\text { Width } \\
\text { (inches) }\end{array}$ & $\begin{array}{c}\text { Size } \\
\left(1000 \text { inch }^{3}\right)\end{array}$ & \\
\hline \multicolumn{8}{|l|}{ Native species } \\
\hline Creeping sand cherry & 12.2 & 28.1 & 96.8 & 9.5 & 29.7 & 90.5 & -6 \\
\hline Elderberry & 26.7 & 25.1 & 162.2 & 42.1 & 34.9 & 949.6 & 485 \\
\hline Gray dogwood & 21.4 & 16.7 & 64.1 & 17.6 & 16.4 & 59.4 & -7 \\
\hline Round leaf dogwood & 27.2 & 19.2 & 100.0 & 23.8 & 21.3 & 146.1 & 46 \\
\hline Virginia rose & 20.5 & 26.2 & 140.5 & 25.0 & 28.1 & 216.9 & 54 \\
\hline Sweetbells & 25.6 & 22.8 & 133.5 & 27.6 & 25.0 & 183.5 & 38 \\
\hline \multicolumn{8}{|l|}{ Non-native species } \\
\hline 'Compactus' winged euonymus & 25.1 & 25.6 & 171.5 & 28.1 & 33.2 & 354.5 & 107 \\
\hline 'Crimson Pygmy' japanese barberry & 16.4 & 21.8 & 79.6 & 16.6 & 29.1 & 142.7 & 79 \\
\hline
\end{tabular}

${ }^{\mathrm{z}} 1$ inch $=2.54 \mathrm{~cm}$

yPlant width was measured twice, at right angles to each measurement, and averaged.

'Plant size was the product of the height and two perpendicular widths; 1 inch $=16.3871 \mathrm{~cm}^{3}$.

wPercent change in plant size was calculated using the formula: (size at $106 \mathrm{WAP}-$ initial size/initial size) $\times 100 \%$.

cherry, gray dogwood, and highbush blueberry showed decreases in plant size, which were slight for sand cherry $(-6 \%)$ and gray dogwood $(-7 \%)$. Reduction in plant size of creeping sand cherry was attributed to white-tailed deer browse, which removed long vigorous shoots that extended the width of the plant, and produced more interior branching. Gray dogwood suffered moderate to heavy white-tailed deer browse and demonstrated little ability to regenerate. Highbush blueberry exhibited dramatic decreases in plant size $(-82 \%)$ because the upper parts of plants had extensive dieback, which had to be pruned out.

The two non-native controls had the highest aesthetic quality rating at 4.5 , which was matched exactly by the native sweetbells (Table 2). Aesthetic quality for virginia rose, northern spicebush, elderberry, and creeping sand cherry were statistically similar to the non-native controls. Gray dogwood, round leaf dogwood, and highbush blueberry had significantly lower aesthetic quality than the nonnative controls.

Sweetbells exhibited high resistance to white-tailed deer browse and was able to tolerate snow load because of its slender flexible stems and its propensity to produce copious suckers from its base. Despite repeated light white-tailed deer browse, virginia rose plants were able to break new buds and retain dense habit and healthy appearance (Fig. 1). Its branches are supple 


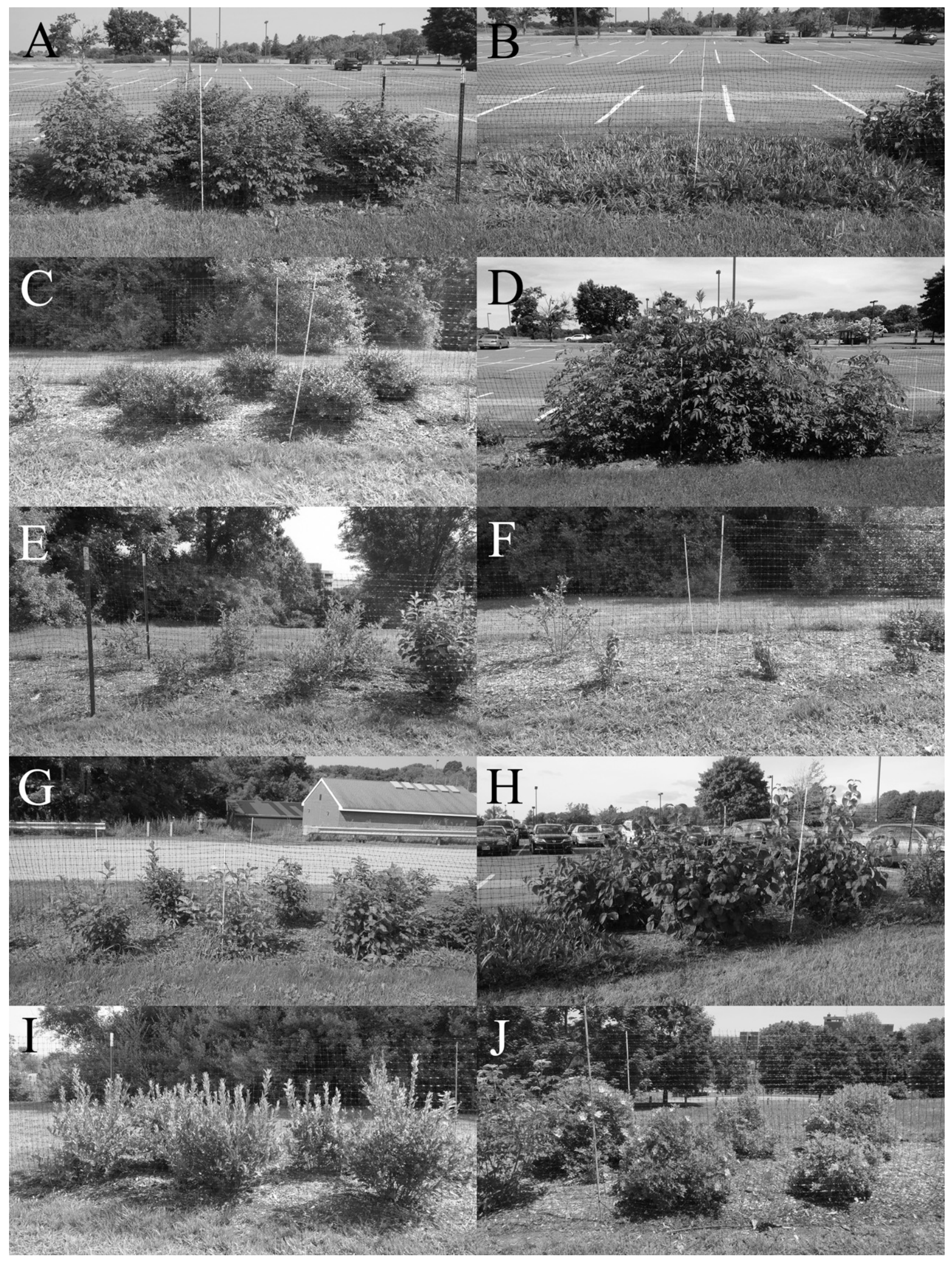

Fig. 1. Photographs of eight Connecticut native species and two non-native species planted in a commuter parking lot on the University of Connecticut campus (Storrs, CT) 2 years after transplanting: (A) 'Compactus' winged euonymus (non-native), (B) creeping sand cherry, (C) 'Crimson Pygmy' japanese barberry (non-native), (D) elderberry, (E) gray dogwood, (F) highbush blueberry, $(G)$ northern spicebush, $(H)$ round leaf dogwood, $(\mathrm{I})$ sweetbells, and $(\mathrm{J})$ virginia rose. 
enough to withstand snow loads and its rhizomatous, suckering nature helped in recovery from white-tailed deer browse and snow impacts. Round leaf dogwood has rigid stems that did suffer light damage from snow load. Many round leaf dogwood plants were so damaged by white-tailed deer that they were unable to recover dense habit even after white-tailed deer exclusion. However, several individuals that had less severe white-tailed deer damage, recovered to produce attractive, dense plants (Fig. 1). Northern spicebush appeared to struggle initially in the full sun parking lot conditions and was not tolerant of white-tailed deer browse. Several individuals of northern spicebush that were less heavily damaged by white-tailed deer grew into attractive shrubs after whitetailed deer exclusion. Highbush blueberry was unable to establish in the difficult parking lot conditions and its brittle stems were broken by snow load. This plant is often touted as an alternative to invasive 'Compactus' winged euonymus because of its red fall color (Abbey, 2004; Burrell, 2006; Cullina, 2003); however, our findings indicate that highbush blueberry is not a suitable replacement for use in difficult landscape conditions where 'Compactus' winged euonymus is frequently used. Gray dogwood naturally grows in dry, infertile and often, exposed sites and is thought of as a tough plant. However, the plants used in this study lacked the vigor necessary to regenerate healthy specimens in a single growing season with white-tailed deer exclusion. After damage from white-tailed deer and snow load, elderberry was quickly able to recover and produced healthy looking plants in one growing season with whitetailed deer exclusion (Fig. 1). Creeping sand cherry performed well overall; however, because of its prostrate growing habit, specimens in one end block were mowed over by landscape crews that did not recognize the plants. Both non-native control species performed well and exhibited all of the traits that have made them popular landscape ornamentals. 'Compactus' winged euonymus plants were grazed by white-tailed deer more heavily than was expected; however, they were able to recover to produce dense, symmetrical specimens. 'Crimson Pygmy' japanese barberry did exhibit damage from snow plows and snow load because plants are low growing and have brittle shoots.

Sweetbells performed exceedingly well in the challenging parking lot conditions and can directly replace invasives in difficult landscape sites. Virginia rose and creeping sand cherry are also suitable replacements for invasives in difficult landscape situations with minimal white-tailed deer presence. Round leaf dogwood, gray dogwood, and northern spicebush may be suitable replacements for invasives in difficult situations if white-tailed deer can be excluded and plants be provided additional care during the first couple of establishment years. Highbush blueberry is not a suitable replacement for invasives in difficult landscape conditions.

\section{Literature cited}

Abbey, T.M. 2004. Alternatives to invasive ornamental plant species. Connecticut Agr. Expt. Sta., New Haven, CT.
Burrell, C.C. 2006. Native alternatives to invasive plants. Brooklyn Botanic Garden, Brooklyn, NY.

Cullina, W. 2002. Native trees, shrubs and vines. Houghton Mifflin, New York, NY.

Cullina, W. 2003. Alternatives to invasive species. New England Wildflower Soc., Framingham, MA.

Dirr, M.A. 2011. Manual of woody landscape plants. 6th ed. Stipes Publishing, Champaign, IL.

Gagliardi, J.A. and M.H. Brand. 2007. Connecticut nursery and landscape industry preferences for solutions to the sale and use of invasive plants. HortTechnology 17:39-45.

Hightshoe, G.L. 1988. Native trees, shrubs and vines for urban and rural America. Wiley, New York, NY.

Lehrer, J.M., M.H. Brand, and J.D. Lubell. 2006. Tackling a thorny issue. Amer. Nurseryman 8(204):30-36.

Lubell, J.D. 2013. Evaluating landscape performance of six native shrubs as alternatives to invasive exotics. Hort Technology 23:119-125.

McCoy, S. 2011. Native plants for all. Amer. Nurseryman 211(1):20-24.

Perdomo, P., P. Nitzsche, and D. Drake. 2004. Landscape plants rated by deer resistance. 7 Nov. 2014. <http://njaes.rutgers. edu/deerresistance $>$.

Tallamy, D.W. 2007. Bringing nature home. Timber Press, Portland, ME.

U.S. Department of Commerce. 2009a. National climatic data center. 24 Oct. 2014. <http://www.ncdc.noaa.gov/IPS/coop/ coop.html?_finish $=0.8448295815271442>$.

U.S. Department of Commerce. 2009 b. National climatic data center. 24 Oct. 2014. <http://www.ncdc. noaa.gov $/$ IPS $/$ coop $/$ coop.html?_finish= $0.20836864321763848>$. 